\title{
Synergistic Effect of Selenium Addition and Water Stress on Melilotus officinalis L. Mineral Content
}

\author{
Panagiota KOSTOPOULOU ${ }^{1 *}$, Apostolos P. KYRIAZOPOULOS ${ }^{2}$, Eleni M. ABRAHAM ${ }^{3}$, \\ Zoi M. PARISSI ${ }^{3}$, Maria KARATASSIOU ${ }^{1}$, Nikolaos BARBAYANNIS ${ }^{4}$ \\ ${ }^{1}$ Aristotle University of Thessaloniki, Department of Forestry and Natural Environment, Laboratory of Rangeland Ecology (286), 54124 Thessaloniki \\ Greece; giotakos@for.auth.gr(*orrespondingauthor);karatass@for.auth.gr \\ ${ }^{2}$ Democritus University of Thrace, Department of Forestry and Management of the Environment and Natural Resources, 193 Pantazidou str., 68200 Orestiada, \\ Greece; apkyriaz@fmenr.duth.gr \\ ${ }_{3}^{3}$ Aristotle University of Thessaloniki, Department of Forestry and Natural Environment, Laboratory of Range Science (236), 54124 Thessaloniki, \\ Greece;eabraham@for.auth.gr;pz@for.auth.gr \\ ${ }^{4}$ Aristotle University of Thessaloniki, Department of Agriculture, Laboratory of Soil Science, 54124 Thessaloniki, \\ Greece; nikbarba@agro.auth.gr
}

\begin{abstract}
The objective of this study was to examine the combined effects of selenium (Se) enrichment and water stress on the accumulation of available macro- and micronutrients in Melilotus officinalis L. aerial parts. Plants of M. officinalis were subjected to three levels of Se addition ( 0,1 and $3 \mathrm{mg} \mathrm{Se} \mathrm{L}^{-1}$ water) and to two water treatments: a) full irrigation and b) limited irrigation (water stress). The above ground biomass (stems and leaves) was analyzed for Se, potassium (K), sodium $(\mathrm{Na})$, magnesium $(\mathrm{Mg})$, iron $(\mathrm{Fe})$, copper $(\mathrm{Cu})$, calcium $(\mathrm{Ca})$, manganese $(\mathrm{Mn})$ and zinc $(\mathrm{Zn})$. Se addition differentially affected the $\mathrm{K}, \mathrm{Mg}$ and $\mathrm{Ca}$ content of $M$. officinalis aerial parts, while it led to the reduction of the micronutrients $\mathrm{Cu}, \mathrm{Fe}$ and $\mathrm{Mn}$. Water stress resulted in the increase of $\mathrm{K}, \mathrm{Na}, \mathrm{Mg}, \mathrm{Ca}$ and $\mathrm{Cu}$, and to the decrease of the Fe, $\mathrm{Zn}$ and $\mathrm{Mn}$ content. An interaction between selenium addition and water treatment was more notable for $\mathrm{Ca}$ and $\mathrm{Mg}$, which decreased under water stress at low Se level and for $\mathrm{Zn}$ and $\mathrm{Cu}$, which increased under water stress at high Se level. According to our findings, Seinduced increased accumulation of some inorganic ions in the aerial parts of this species under water stress conditions could serve as a means to alleviate the adverse impact of water deficit on important metabolic processes, enhancing $M$. officinalis tolerance to water stress.
\end{abstract}

Keywords: limited irrigation, macro-nutrients, micro-nutrients, sodium selenate, yellow sweetclover

\section{Introduction}

Water comprises one of the most important determinants of plant production and distribution on earth. Water deficit is considered as a crucial factor that decreases the crop yield around the world (Valliyodan and Nguyen, 2006), suppressing plant growth and development due to reduced water absorption and nutrient intake (Gunes et al., 2007; Ciríaco da Silva et al., 2011). One of the most important effects of water deficit is on transport of nutrients to the root and on root growth and extension (Fageria et al., 2002; Samarah et al., 2004). Decreased water availability affects the absorbance of nutrients from plant tissues (Mengel and Kirkby, 2001; Amtmann and Blatt, 2009). Water stress is generally regarded to reduce nutrient uptake by roots and their translocation to the shoots due to its negative effect on transpiration rate, active transport and membrane permeability (Marschner, 1995; Alam, 1999; Baligar et al., 2001).
Nevertheless, numerous studies have shown that many species accumulate inorganic ions as a means to adapt to water stress (Patakas et al., 2002; Zhu et al., 2005), increasing in this way their drought resistance.

Selenium (Se) is an essential trace element for livestock (Mayland, 1994; Gupta and Gupta, 2000), as it is necessary for growth and fertility in animals (Hatch, 1982; Rogers, 1990). Although selenium is not considered as an essential element for plant metabolism (Saggoo et al., 2004) and nutrition of higher plants (Terry et al., 2000), there is evidence that at low concentrations it can modify the uptake and accumulation of essential minerals important for plant metabolism (Pazurkiewicz-Kocot et al., 2003), increase plant resilience to oxidative stress, stimulate plant growth and delay plants senescence (Hartikainen et al., 2000; Xue et al., 2001; Simojoki et al., 2003; Hajiboland and Amjad, 2007). Thus, Se at lower levels 
Table 1. Properties of farm soil used in the experimental pots

\begin{tabular}{|c|c|c|c|c|c|c|c|c|c|c|}
\hline $\mathrm{pH}$ & $\begin{array}{l}\text { Organic } \\
\text { matter \% }\end{array}$ & $\begin{array}{c}\mathrm{N} \text { total } \\
\%\end{array}$ & $\begin{array}{c}\mathrm{P} \\
\mathrm{mg} \mathrm{kg}^{-1}\end{array}$ & $\begin{array}{c}\mathrm{K} \\
\mathrm{mg} \mathrm{kg}^{-1}\end{array}$ & $\begin{array}{c}\mathrm{Na} \\
\mathrm{mg} \mathrm{kg}^{-1}\end{array}$ & $\begin{array}{c}\text { CEC } \\
\mathrm{meq} / 100 \mathrm{~g}\end{array}$ & $\begin{array}{c}\mathrm{CaCO}_{3} \\
\%\end{array}$ & $\begin{array}{c}\text { Sand } \\
\%\end{array}$ & $\begin{array}{l}\text { Silt } \\
\%\end{array}$ & $\begin{array}{l}\text { Clay } \\
\%\end{array}$ \\
\hline 8.5 & 0.5 & 0.4 & 5.0 & 52 & 92 & 5.5 & 7.5 & 51 & 39 & 10 \\
\hline
\end{tabular}

could probably contribute to increase drought resistance in plants. However, in higher levels Se can be toxic (Terry et al., 2000).

Se uptake by plants is governed by soil and plant factors. Among them the most important is its form and concentration in the soil (Wu et al., 1994). Moreover, soil moisture affects soil Se availability for plant uptake (Banuelos and Meek, 1989). Several studies on soils enriched with Se (Wu et al., 1993; 1996) found a strong relationship between water supply and Se accumulation by plant tissues. According to Kuznetsov et al. (2003), Se can stimulate more efficient water absorption through roots, and thereby decrease water loss from plant tissues.

Similarly to other heavy metals, Se can modify the uptake and accumulation of macro and micro-nutrients which are important for plant metabolism (Kopsell et al., 2000; Pazurkiewicz-Kocot et al., 2003; Tennant and Wu, 2000). Kostopoulou et al. (2015) reported various changes in macronutrient concentrations of Se enriched plants, while the micronutrient content decreased significantly. Generally, Se in high concentrations may compete with $\mathrm{S}$ and $\mathrm{P}$ (Tennant and Wu, 2000) but the effects on the uptake of other nutrients in plants are not very clear (Feng et al., 2009).

Legume species are considered to accumulate greater amounts of Se than grasses (Mackowiak and Amacher, 2003). However, the ability of forage legumes to accumulate Se has been studied only in limited number of species, such as Trifolium repens and Medicago sativa (Terry et al., 2000; Mackowiak and Amacher, 2003). Melilotus officinalis L. (yellow sweetclover) is a biennial legume species, considered as palatable forage of high quality both for livestock and wildlife (Mueggler and Stewart, 1980). This species has the ability to accumulate more than 100 $\mathrm{mg} \mathrm{Se} \mathrm{kg}{ }^{-1} \mathrm{DM}$ in its tissues when irrigated with sodium selenate solution (Kostopoulou et al., 2010). Therefore, it could be used either as a dietary supplement, in mixture with non-accumulator species, for livestock feed deficient in Se or for restoration of grasslands in seleniferous soils (Kostopoulou et al., 2015).

Limited number of studies has evaluated the combined effects of Se concentration and water deficit conditions on the mineral content of plant species. Thus, the objective of this study was to examine if the synergism of Se concentration and water stress enhanced the uptake of available macro- and micronutrients by Melilotus officinalis tissues.

\section{Materials and Methods}

\section{Description of the study site}

The study was conducted at the farm of Aristotle University of Thessaloniki, $14 \mathrm{~km}$ south of the city of Thessaloniki $\left(40^{\circ} 32^{\prime} \mathrm{N}, 22^{\circ} 59^{\prime} \mathrm{E}\right)$, at an elevation of about $5 \mathrm{~m}$ a.s.l. in spring 2002. The climate of the area, according to the bioclimatogram of Emberger (1942), could be characterized as Mediterranean semi-arid with cold winters. For the period 1978-2008, the mean annual temperature of the site was $15.5^{\circ} \mathrm{C}$ and the mean annual rainfall $446 \mathrm{~mm}$.

\section{Biological material}

In February, seeds (commercial seedlot of Spanish origin) of yellow sweetclover (M. officinalis L.) were sown in each of sixty pots. All pots were 25 liters in volume and were filled with a 5:4:1:1 (on a volume basis) peat:soil:manure:sand mixture. The mixture comprised of white peat medium bedding, enriched with nutrients and trace elements (Klassmann TS1, Klassmann-Deilmann GmbH, Geeste, Germany), grassland soil (0-20 cm), classified as Typic Xerorthent (USDA-NRCS 1996), collected the same year from the farm of the Aristotle University of Thessaloniki, used as a managed grassland, farmyard manure and sand. Selenium concentration in the substrate was less than $1 \mathrm{mg} \mathrm{kg}^{-1} \mathrm{dw}$. Soil properties are presented in Table 1.

\section{Experimental design}

After seedling emergence (March 2002), the pots were thinned to a total of 10 seedlings per pot. Then the pots were transferred under a permanent rain shelter, a wooden construction of $2.5 \mathrm{~m}$ height, with a transparent plastic cover on top. The rain shelter was designed in such a way as to avoid rainfall reaching the pots, while keeping the atmospheric conditions unchanged. The pots were randomly divided in three groups of twenty pots each. The first group was irrigated only with tap water ( $0 \mathrm{mg} \mathrm{Se} \mathrm{L}^{-1}$ water); the second group was irrigated with a $1 \mathrm{mg} \mathrm{Se} \mathrm{L}^{-1}$ tap water solution and the third group received a $3 \mathrm{mg} \mathrm{Se} \mathrm{L}^{-1}$ tap water solution, both resulting from aqueous $\mathrm{Na}_{2} \mathrm{SeO}_{4}$ (sodium selenate) dilution. Each of these groups was also divided into two subgroups of ten pots each: one subgroup (ten pots) was irrigated frequently (Full Irrigation) so that the soil in the pots was always near field capacity, as determined by tensiometers. The other subgroup (ten pots) received $50 \%$ less water than the fully irrigated plants (Limited Irrigation - Water Stress). Consequently, six treatments were established: a) No Se - Full Irrigation, b) No $\mathrm{Se}$ - Limited Irrigation, c) $1 \mathrm{mg} \mathrm{Se} \mathrm{L}^{-1}$ water - Full Irrigation, d) $1 \mathrm{mg} \mathrm{Se} \mathrm{L}^{-1}$ water - Limited Irrigation, e) $3 \mathrm{mg} \mathrm{Se} \mathrm{L}^{-1}$ water Full Irrigation and f) $3 \mathrm{mg} \mathrm{Se} \mathrm{L^{-1 }}$ water - Limited Irrigation. The total duration of the experiment was 45 days.

\section{Sampling and chemical analysis}

By the end of the experimental period the herbage biomass from all treatments was cut to ground level. The above ground biomass (stems and leaves) was rinsed with deionized water, then dried for $48 \mathrm{~h}$ at $60^{\circ} \mathrm{C}$ and ground through to $\leq 1 \mathrm{~mm}$ screen. Selenium concentration was determined colorimetrically after digestion using a combination of $\mathrm{HNO}_{3}$ $\mathrm{HClO}_{4}$ (Holtzklaw et al., 1987). A sample of $1 \mathrm{~g}$ from each tissue material was dry-ashed in a $\mathrm{HCl} 2 \mathrm{~N}$ solution at $500{ }^{\circ} \mathrm{C}$ for $16 \mathrm{~h}$. Potassium and $\mathrm{Na}$ concentration was determined using a flame photometer (PFP7, Jenway, Essex, England), while $\mathrm{Mg}, \mathrm{Fe}, \mathrm{Cu}, \mathrm{Ca}, \mathrm{Mn}$ and $\mathrm{Zn}$ concentration was determined with an atomic absorption spectrophotometer (AA-6300, Shimadzu Corporation, Tokyo, Japan). 


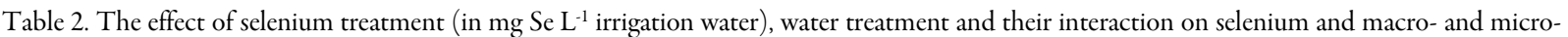
mineral content (in $\mathrm{mg} \mathrm{kg}^{-1}$ dry weight) of Melilotus officinalis aerial parts. Data represent means ( $\mathrm{n}=6$ for selenium treatments and $\mathrm{n}=9$ for irrigation treatments $) \pm$ standard error. Different letters in each column indicate significant differences $(\mathrm{p}<0.05)$

\begin{tabular}{|c|c|c|c|c|c|c|c|c|c|}
\hline & Se & $\mathbf{K}$ & $\mathrm{Na}$ & Mg & $\mathrm{Ca}$ & $\mathrm{Cu}$ & $\mathbf{F e}$ & $Z_{n}$ & Mn \\
\hline \multicolumn{10}{|c|}{ Selenium treatment } \\
\hline 0 & $9 \pm 1^{a}$ & $48896 \pm 1855^{a}$ & $638 \pm 35$ & $7647 \pm 362^{a}$ & $29119 \pm 1222^{a}$ & $20.1 \pm 0.3^{\mathrm{a}}$ & $1968 \pm 329^{a}$ & $109 \pm 7$ & $173 \pm 13^{a}$ \\
\hline 1 & $136 \pm 4^{b}$ & $48846 \pm 167^{a}$ & $656 \pm 20$ & $8115 \pm 204^{b}$ & $30465 \pm 258^{b}$ & $17.0 \pm 0.3^{b}$ & $1081 \pm 104^{b}$ & $97 \pm 3$ & $128 \pm 5^{b}$ \\
\hline 3 & $186 \pm 4^{c}$ & $52848 \pm 644^{b}$ & $688 \pm 13$ & $7440 \pm 35^{c}$ & $26528 \pm 758^{c}$ & $17.5 \pm 0.6^{b}$ & $812 \pm 86^{c}$ & $95 \pm 5$ & $103 \pm 5^{c}$ \\
\hline Significance & $* * *$ & $* * *$ & ns & $* * *$ & $* * *$ & ** & *** & ns & $* * *$ \\
\hline \multicolumn{10}{|c|}{ Irrigation treatment } \\
\hline Full & $110 \pm 26$ & $48222 \pm 967$ & $617 \pm 15$ & $7619 \pm 252$ & $27410 \pm 926$ & $17.9 \pm 0.6$ & $1667 \pm 263$ & $103 \pm 6$ & $147 \pm 14$ \\
\hline Limited & $111 \pm 26$ & $52171 \pm 766$ & $705 \pm 12$ & $7850 \pm 159$ & $29998 \pm 529$ & $18.5 \pm 0.6$ & $907 \pm 91$ & $98 \pm 3$ & $122 \pm 7$ \\
\hline Significance & ns & $* * *$ & $* * *$ & $* * *$ & $* * *$ & ** & $* * *$ & ** & $* * *$ \\
\hline \multicolumn{10}{|c|}{ Se $\mathrm{x}$ irrigation treatment interaction } \\
\hline Significance & ** & *** & * & $* * *$ & *** & $* * *$ & *** & $* * *$ & ** \\
\hline
\end{tabular}

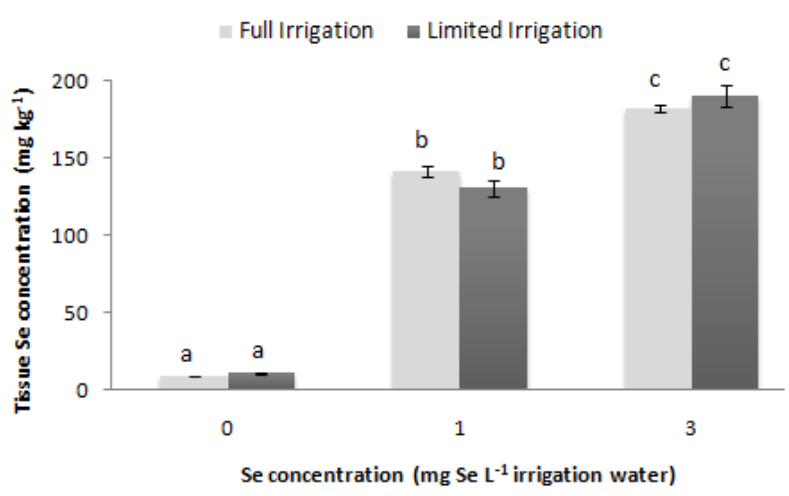

Fig. 1. Mean values $(n=3) \pm$ S.E. of selenium concentration in the aerial parts of Melilotus officinalis seedlings. Plants were subjected to three different Se concentrations (0,1 and $3 \mathrm{mg}$ Se $\mathrm{L}^{-1}$ irrigation water) and two water regimes (full and limited irrigation). Different letters in each column indicate significant differences $(\mathrm{p}<0.05)$

\section{Statistical analysis}

A split-plot experimental design was followed with ten replications for each treatment. Statistical analysis of the data was performed using ANOVA with the help of the SPSS ${ }^{\circ}$ statistical software v. 22.0 (SPSS Inc., Chicago, IL, USA). Tukey test at 0.05 level of significance was used to determine differences among means.

\section{Results}

The accumulation of $\mathrm{Se}, \mathrm{K}, \mathrm{Mg}, \mathrm{Ca}, \mathrm{Cu}, \mathrm{Fe}$ and $\mathrm{Mn}$ in the aerial parts (stems and leaves) of $M$. officinalis seedlings (across the irrigation level) was significantly affected by the addition of sodium selenate in the soil (Table 2), while the accumulation of $\mathrm{Na}$ and $\mathrm{Zn}$ was not affected $(\mathrm{P} \geq 0.05)$. In particular, the addition

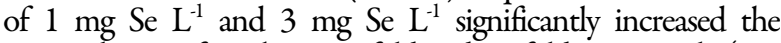
accumulation of Se about 15-fold and 20-fold respectively (Fig. 1). Similarly, the level of $\mathrm{K}$ was significantly increased but only with the addition of $3 \mathrm{mg} \mathrm{Se} \mathrm{L}^{-1}$. Moreover, the addition of $1 \mathrm{mg}$ Se $\mathrm{L}^{-1}$ significantly increased the accumulation of $\mathrm{Mg}$ about $6 \%$ and $\mathrm{Ca}$ about $5 \%$, while the addition of $3 \mathrm{mg} \mathrm{Se} \mathrm{L}^{-1}$ significantly reduced the level of $\mathrm{Mg}$ and $\mathrm{Ca}$ about 3\% and 9\% respectively (Table 2, Fig. 2). As far as the micronutrients were concerned, the accumulation of $\mathrm{Cu}$ was significantly higher in the control treatment (no Se), while it did not significantly differ between the levels of sodium selenate (Table 2). Conversely, the content of Fe and Mn was gradually reduced with the addition of $1 \mathrm{mgSe}$ $\mathrm{L}^{-1}$ and $3 \mathrm{mgSe} \mathrm{L}^{-1}$.

The water treatment significantly affected the macro and micro-nutrient content (across the sodium selenate levels) but not the content of Se in the aerial parts of $M$. officinalis seedlings (Table 2). Specifically, the content of $\mathrm{K}, \mathrm{Na}, \mathrm{Mg}$, $\mathrm{Ca}$ and $\mathrm{Cu}$ was significantly higher about $8 \%, 14 \%, 3 \%, 9 \%$ and $3 \%$ respectively under limiting irrigation compared to full one (Table 2). Inversely, the content of $\mathrm{Fe}, \mathrm{Zn}$ and $\mathrm{Mn}$ was significantly lower about $46 \%, 5 \%$ and $17 \%$ respectively.

A significant interaction between the water treatment and the level of selenium addition was observed for the accumulation of all macro and micro-nutrients (Table 2), indicating that the effect of the irrigation treatment was not consistent in the level of sodium selenate. Thus, the concentration of Se did not significantly differ between full and limited irrigation without sodium selenate. On the contrary, the limiting irrigation with sodium selenate solution of $1 \mathrm{mg} \mathrm{Se} \mathrm{L}^{-1}$ decreased and of $3 \mathrm{mg} \mathrm{Se}$ $\mathrm{L}^{-1}$ increased the concentration of Se in the aerial parts of the plants respectively (Fig. 1) in comparison with the full irrigation. The concentration of $\mathrm{K}$ and $\mathrm{Na}$ was significantly higher under water stress compared to full irrigation with and without the addition of sodium selenate (Fig. 2). The concentration of $\mathrm{Mg}$ and $\mathrm{Ca}$ was significantly lower under limited irrigation with the solution of $1 \mathrm{mg} \mathrm{Se} \mathrm{L}^{-1}$ compared to full irrigation, whereas the opposite trend was observed under limited irrigation with the solution of $3 \mathrm{mgSe} \mathrm{L}^{-1}$ and without sodium selenate.

Regarding the micro-nutrients, the concentration of $\mathrm{Cu}$ did not significantly differ between full and limiting irrigation without sodium selenate and with $1 \mathrm{mg} \mathrm{Se} \mathrm{L^{- }}$. However, the concentration of $\mathrm{Cu}$ was significantly higher

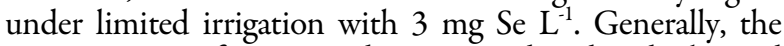
concentration of Fe, $\mathrm{Zn}$ and $\mathrm{Mn}$ was reduced under limited irrigation with and without sodium selenate. The only exception was the concentration of $\mathrm{Zn}$ under limiting irrigation with solution of $3 \mathrm{mg} \mathrm{Se} \mathrm{L}^{-1}$ which was significantly higher in comparison with that under full irrigation. 

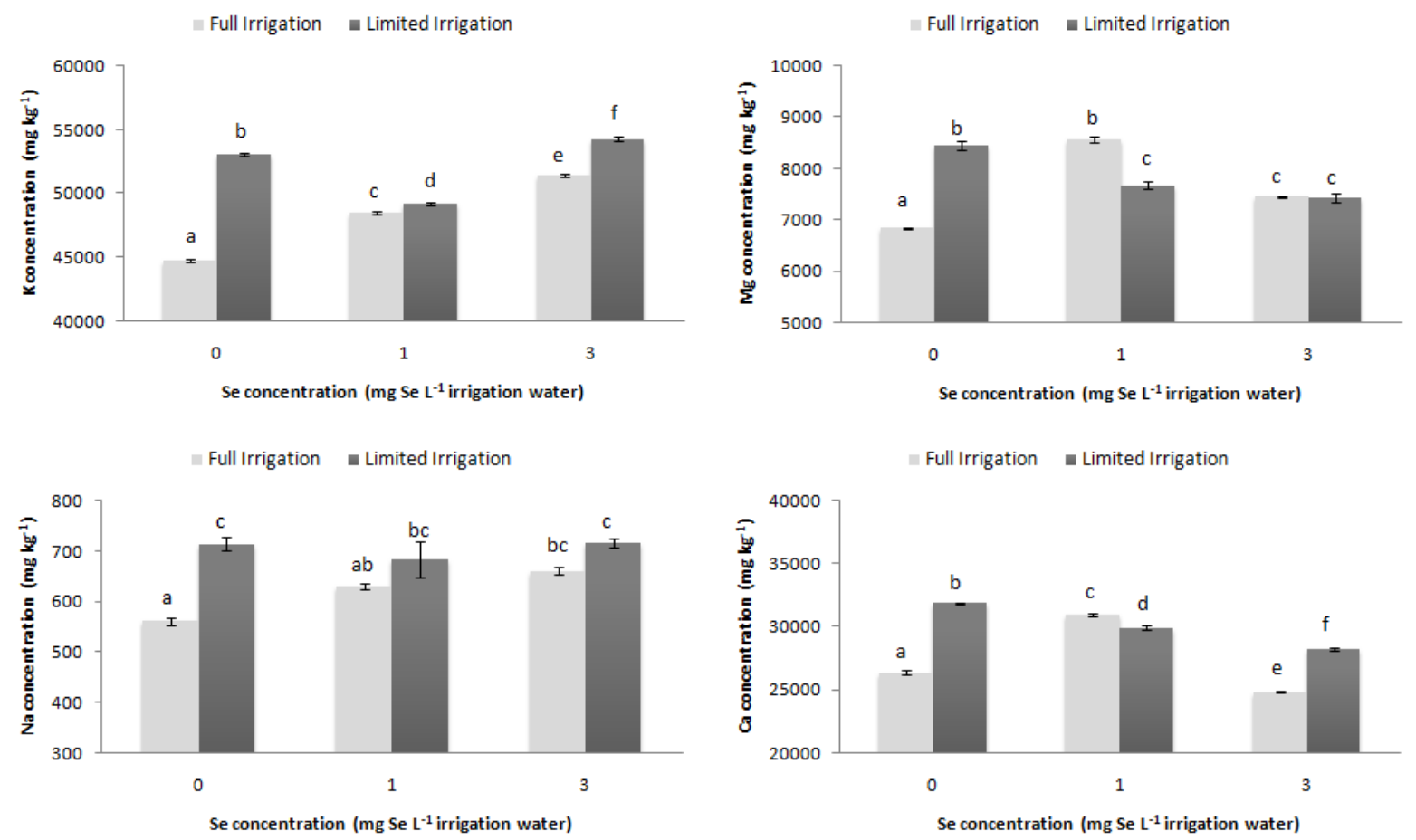

Fig. 2. Mean values $(n=3) \pm$ S.E. of macro-mineral content in the aerial parts of Melilotus officinalis seedlings. Plants were subjected to three different Se concentrations ( 0,1 and $3 \mathrm{mg} \mathrm{Se} \mathrm{L}^{-1}$ irrigation water) and two water regimes (full and limited irrigation). Different letters in each column indicate significant differences $(\mathrm{p}<0.05)$
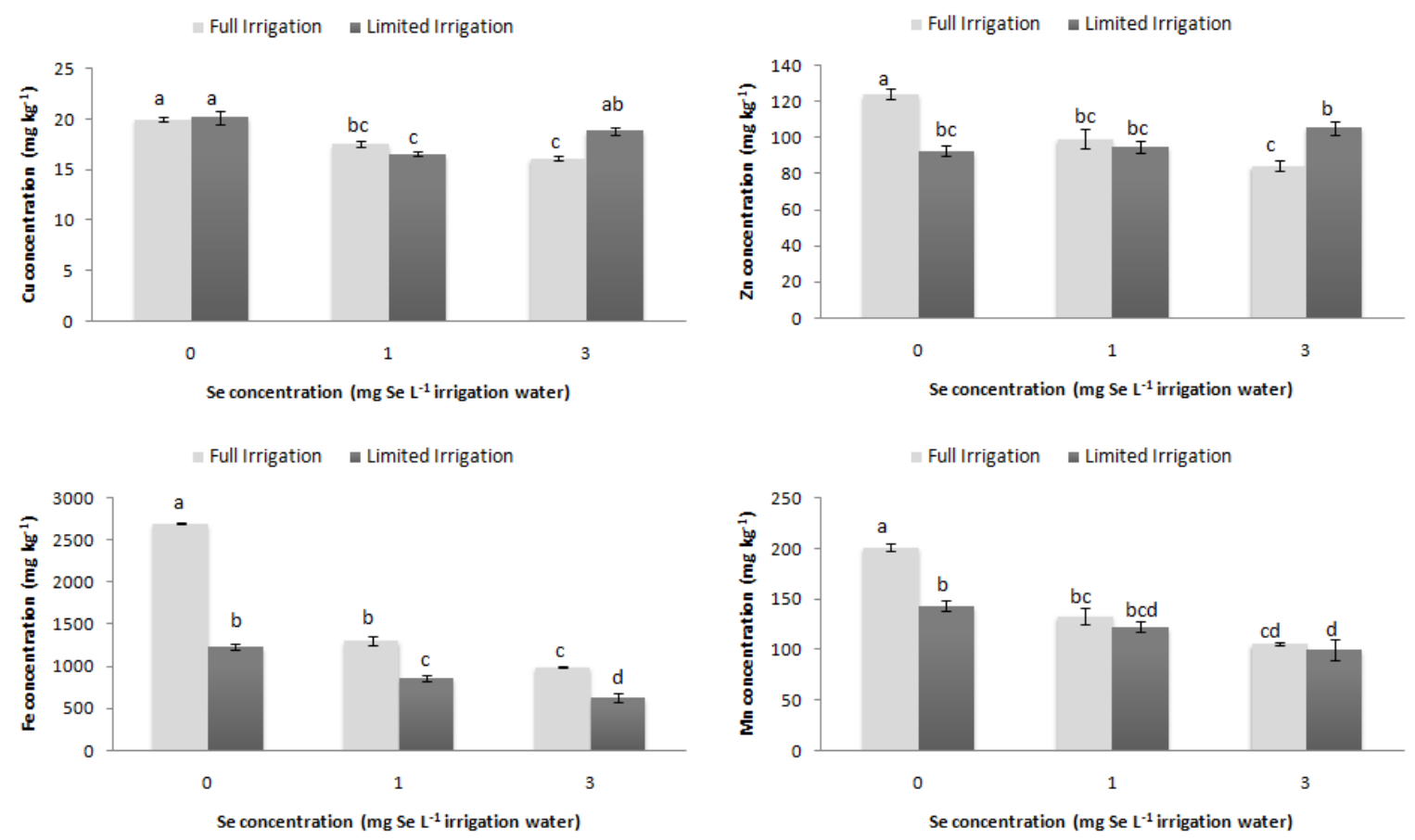

Fig. 3. Mean values $(n=3) \pm$ S.E. of micro-mineral content in the aerial parts of Melilotus officinalis seedlings. Plants were subjected to three different Se concentrations ( 0,1 and $3 \mathrm{mg} \mathrm{Se} \mathrm{L}^{-1}$ irrigation water) and two water regimes (full and limited irrigation). Different letters in each column indicate significant differences $(\mathrm{p}<0.05)$ 


\section{Discussion}

\section{Effect of selenium addition}

A relatively high amount of $\mathrm{Se}$ in tissues of $M$. officinalis was observed as the selenate addition increased in the treatments. Similarly, Kopsell et al. (2000) found that Se increased linearly in response to increasing sodium selenate concentrations in Brassica oleracea leaves. According to $\mathrm{Li}$ et al. (2008) selenate is easily taken up by plant roots and since it is extremely mobile in xylem transport, it is distributed quickly to the plant shoots.

Adding sodium selenate affected the $\mathrm{K}$ content in the aerial parts of $M$. officinalis. Se addition at low level decreased $\mathrm{K}$ content, while at the higher Se level, an increment of $\mathrm{K}$ was detected. Similar results were also reported for $M$. officinalis (Kostopoulou et al., 2015) and Brassica oleracea leaves (Kopsell et al., 2000), suggesting a possible involvement of this element in the tolerance mechanism of Se (Kostopoulou et al., 2015). On the contrary, Hawrylak-Novak (2008) reported that at low Se concentration in the nutrient solution, $\mathrm{K}$ content in the aerial parts of maize plants increased, while at high Se concentration the opposite effect was found. On the other hand, Wu and Huang (1992) found that tissue K concentration of Trifolium repens and Festuca arundinacea was not affected by Se.

The addition of sodium selenate did not affect the level of $\mathrm{Na}$ in the aerial parts of $M$. officinalis. Kostopoulou et al. (2015) found that $\mathrm{Na}$ concentration was increased in the shoots, but there was no increase in the leaves, after the addition of sodium selenate. The $\mathrm{Ca}$ and $\mathrm{Mg}$ concentrations were affected by sodium selenate addition, with an increase at the low and a decrease at the high level. Feng et al. (2009) have found contrasting results. According to their research, at low Se content $\mathrm{Ca}$ and $\mathrm{Mg}$ concentration in Pteris vittata decreased, whereas at high Se it increased. On the other hand, Kopsell et al. (2000) found that $\mathrm{Ca}$ concentration in B. oleracea plants was not affected by Se addition, while Hawrylak- Novak (2008) found that its content in shoots of maize plants increased after Se addition. It is obvious from this wide variability of the results regarding the effect of selenium on plant mineral content that the effects of Se are species-dependent. In addition, selenium chemical form, its concentration in the nutrient solution and the plant's developmental stage in each experiment also play a significant role on the effect of Se on plants (Hartikainen et al., 2000; Xue et al., 2001; Hawrylak-Nowak, 2008). Unfortunately there were scant studies about the effect of Se on the uptake of macro- and micro- elements in plants (Feng et al., 2009) and for this reason their results are not always definite (HawrylakNowak, 2008).

Sodium selenate uptake by $M$. officinalis tissues reduced the micronutrient content in aerial parts of the plant. This result is in agreement with the general assumption that absorption of elements such as $\mathrm{Mn}, \mathrm{Zn}, \mathrm{Cu}$ and Fe is inhibited by increasing Se levels (Kabata-Pendias and Pendias, 2001; Fargašová et al., 2006). Moreover, similar results have been found in a previous experiment using $M$. officinalis (Kostopoulou et al., 2015). However, contrasting results have been reported in other plant species. According to Wu and Huang (1992) Mn, Fe and $\mathrm{Zn}$ increased under Se treatment in Trifolium repens, while $\mathrm{Cu}$ content was not affected. Total $\mathrm{Cu}, \mathrm{Mn}$ and $\mathrm{Zn}$ content was unaffected by the addition of Se in Brassica olearacea (Kopsell et al., 2000).
Effect of water treatment

There was no significant effect of limited irrigation in the concentration of Se. This result is inconsistent with the results of Tennant and Wu (2000) who found an increment of the concentration of Se in Festuca arundinacea Schreb under water deficit.

Concerning the macro-nutrients $\mathrm{K}, \mathrm{Na}, \mathrm{Mg}$ and $\mathrm{Ca}$, there was an increase in their concentration under water stress. These results are in agreement with those of Tennant and $\mathrm{Wu}$ (2000) for Festuca arundinacea. However, Hu and Schmidhalter (2005) have reported a decrease in the above macronutrients under water stress in Triticum aestivum. The difference in these results could be associated to several factors, as the experimental conditions, plant species and duration of water stress (Tennant and $\mathrm{Wu}, 2000)$. Potassium plays an important role in survival of plants under abiotic stress (Waraich et al., 2011), contributing to osmotic adjustment (Utrillas et al., 1995; Patakas et al., 2002). Leaf $\mathrm{K}$ increase could have contributed to the osmotic adjustment of $M$. officinalis plants, acting as a mechanism to maintain turgor pressure and stomatal conductance (Patakas et al., 2002) and, hence, photosynthesis under water stress conditions (Waraich et al., 2011). In compliance with this result, Kostopoulou et al. (2010) in their study found that stomatal conductance of $M$. officinalis under similar experimental conditions was not affected by water deficit. On the other hand, little information is available on the effect of water stress on $\mathrm{Na}$ and $\mathrm{Mg}$. A decrease in sodium content of Cynodon dactylon was also observed under water deficit conditions (Utrillas et al., 1995). On the contrary, plants of Sorghum bicolor grown on different irrigation regimes did not differ in the concentration of $\mathrm{Na}$ (Asgharipour and Heidari, 2011). Moreover, Karimi and Hasanpour (2014) have found similar results for $\mathrm{Mg}$ for Punica granatum. Magnesium plays a significant role in reducing the generation of reactive oxygen species, protecting the chloroplasts from photo-oxidative damage under water stress (Waraich et al., 2011). Calcium, on the other hand, has a prominent role in maintaining cell structure (McLaughlin and Wimmer, 1999) and recovery after a period of water stress (Palta, 1990). Increase of Ca under water deficit has been reported by others (Utrillas et al., 1995; Patakas et al., 2002).

Information dealing with the effect of water stress on the concentration of micro-minerals in plant tissues is rather scarce. In the present study, the limited irrigation resulted to a reduced concentration of the micronutrients $\mathrm{Fe}, \mathrm{Zn}$ and $\mathrm{Mn}$ in the aerial parts of $M$. officinallis. Generally, water stress reduces nutrient uptake by roots through the decrease in the diffusion rate of nutrients in the soil towards the absorbing root surface (Pinkerton and Simpson, 1986; Alam, 1999). Additionally, it also reduces the transport from the roots to the shoots due to restricted transpiration rates, impaired active transport and membrane permeability (Viets, 1972; Alam, 1999). According to $\mathrm{Hu}$ and Schmidhalter (2005) low soil moisture can induce deficiencies in $\mathrm{Mn}, \mathrm{Fe}$ and $\mathrm{Zn}$. The only exception was the $\mathrm{Cu}$ concentration which was increased, but this was obvious only with the addition of sodium selenate (Fig. 3). Copper is required for lignin synthesis, needed for cell wall strength and prevention of wilting. Increase of $\mathrm{Cu}$ content could alleviate the adverse effects of drought by reducing dieback of stems, yellowing of leaves and stunted growth (Waraich et al., 2011). 
452

Interaction between selenium addition and water treatment

There was a notable interaction between water treatment and addition of sodium selenate in the soil only for $\mathrm{Ca}$ and $\mathrm{Mg}$ concentrations that decreased under water stress at the low Se level. However, under the addition of $3 \mathrm{mg} \mathrm{Se} \mathrm{L}^{-1}$, Ca has followed the same pattern as the other macro-nutrients, while $\mathrm{Mg}$ had no significant difference in its concentration. Water treatment could affect the nutrient balance in plants (Romero $e t$ al., 2004). Its combination with Se addition at various levels could have contrasting effects on nutrient uptake.

Interaction between water treatment and addition of sodium selenate in the soil was notable only for $\mathrm{Zn}$ and $\mathrm{Cu}$, the content of which increased under water stress with the addition of $3 \mathrm{mg}$ Se $\mathrm{L}^{-1}$. Accumulation of inorganic ions may contribute to the adaptation of this species to water stress (Kostopoulou et al., 2012). This could be attributed to the defence mechanism of the plants to water deficit and the antioxidant activity of selenium. Selenium has been recently reported to improve drought resistance in several species, mainly by mitigating the water deficit stress damages in plants (Nejat et al., 2009; Valadabadi et al., 2010; Soleimanzadeli, 2012; Proietti et al., 2013; Emam et al., 2014). The protective role of Se under water stress has been attributed to the protection of cells from oxidative damages (Xue et al., 2001; Prioetti et al., 2013; Habibi, 2013; Ibrahim, 2014), to the regulation of water status of plants (Prioetti et al., 2013; Nawaz et al., 2014), to the increase in root activity (growth and uptake) (Prioetti et al., 2013; Nawaz et al., 2014) and to the prevention of chlorophyll degradation under water stress (Seppanen et al., 2003). In addition, the application of selenium enhanced the antioxidant defence in sorghum (Djanaguiraman et al., 2010) by increasing the antioxidant enzyme activities. This antioxidative effect in soybean (Djanaguiraman et al., 2005) was associated with an increase in superoxide dismutase $(\mathrm{Cu} / \mathrm{ZnSOD})$ and glutathione peroxidase (GSH-Px) enzymes activity. However, the physiological and molecular mechanisms that underlie the beneficial role of selenium in plants need to be further explored.

\section{Conclusions}

Limited Se addition differentially affected the $\mathrm{K}, \mathrm{Mg}$ and $\mathrm{Ca}$ content of $M$. officinalis aerial parts, while it led to the reduction of the micronutrients $\mathrm{Cu}, \mathrm{Fe}$ and $\mathrm{Mn}$. Water stress resulted in the increase of $\mathrm{K}, \mathrm{Na}, \mathrm{Mg}, \mathrm{Ca}$ and $\mathrm{Cu}$, and to the decrease of the $\mathrm{Fe}, \mathrm{Zn}$ and $\mathrm{Mn}$ content. An interaction between selenium addition and water treatment was more notable for $\mathrm{Ca}$ and $\mathrm{Mg}$, which decreased under water stress at low Se level and for $\mathrm{Zn}$ and $\mathrm{Cu}$, which increased under water stress at high Se level According to our findings, Se-induced increased accumulation of some inorganic ions in the aerial parts of this species under water stress conditions could serve as a means to alleviate the adverse impact of water deficit on important metabolic processes, enhancing $M$. officinalis tolerance to water stress. However, the role of Se on nutrient accumulation and on plants' water stress resistance needs to be further elucidated.

\section{Acknowledgements}

The first author would like to thank the Greek National Scholarships Foundation for financial support.

\section{References}

Alam SM (1999). Nutrient uptake by plants under stress conditions. In: Pessarakli M (Ed). Handbook of Plant and Crop Stress, Marcel Dekker, New York pp 285-314.

Amtmann A, Blatt MR (2009). Regulation of macronutrient transport. New Phytologist 181:35-52.

Asgharipour MR, Heidari M (2011). Effect of potassium supply on drought resistance in sorghum: plant growth and macronutrient content. Pakistan Journal of Agricultural Sciences 48(3):197-204.

Baligar VC, Fageria NK, He ZL (2001). Nutrient use efficiency in plants. Communications in Soil Science and Plant Analysis 32:921-950.

Banuelos GS, Meek GE (1989). Accumulation of selenium in selected vegetables. Journal of Plant Nutrition 12:1255-1272.

Ciríaco da Silva E, Nogueira RJMC, Almeida da Silva M, Bandeira de Albuquerque M (2011). Drought stress and plant nutrition. Plant Stress 5(1):32-41.

Djanaguiraman M, Durga Devi D, Shanker AK, Annie Sheeba J, Bangarusamy U (2005). Selenium - an antioxidative protectant in soybean during senescence. Plant and Soil 272:77-86.

Djanaguiraman M, Prasad PVV, Seppanen M (2010). Selenium protects sorghum leaves from oxidate damage under high temperature stress by enhancing antioxidant defense system. Plant Physiology and Biochemistry 48(12):999-1007.

Emam MM, Khattab HE, Helal NM, Deraz AE (2014). Effect of selenium and silicon on yield quality of rice plant grown under drought stress. Australian Journal of Crop Science 8(4):596605.

Emberger L (1942). Un project d'une classification des climates du point de vue phytogeographigue. Bulletin de la Societe d'Histoire Naturelle de Toulouse 77:97-124.

Fageria NK, Baligar VC, Clark RB (2002). Micronutrients in crop production. Advances in Agronomy 77:185-267.

Fargašová A, Pastierová J, Svetková K (2006). Effect of Se-metal pair combinations $(\mathrm{Cd}, \mathrm{Zn}, \mathrm{Cu}, \mathrm{Pb})$ on photosynthetic pigments production and metal accumulation in Sinapis alba L. seedlings. Plant, Soil and Environment 52:8-15.

Feng R, Wei C, Tu S, Wu F (2009). Effects of Se on the uptake of essential elements in Pteris vittata L. Plant and Soil 325:123132.

Gunes A, Inal A, Adak MS, Alpaslan M, Bagci EG, Erol T, Pilbeam DJ (2007). Mineral nutrition of wheat, chickpea and lentil as affected by intercropped cropping and soil moisture. Nutrient Cycling in Agroecosystems 78:83-96.

Gupta UC, Gupta SC (2000). Selenium in soils and crops, its deficiencies in livestock and humans: implications for management. Communications in Soil Science and Plant Analysis 31(11-14):1791-1807.

Habibi G (2013). Effect of drought stress and selenium spraying on photosynthesis and antioxidant activity of spring barley. Acta Agriculturae Slovenica 101:31-39. 
Hajiboland R, Amjad L (2007). Does antioxidant capacity of leaves play a role in growth response to selenium at different sulfur nutritional status? Plant Soil and Environment 53:207215.

Hartikainen H, Xue T, Piironen V (2000). Selenium as an antioxidant and pro-oxidant in ryegrass. Plant and Soil 225:193-200.

Hatch RC (1982). Veterinary toxicology. In: Booth NH, McDonald LE (Eds). Veterinary Pharmacology and Therapeutics pp 965-969.

Hawrylak-Nowak B (2008). Changes in anthocyanin content as indicator of maize sensitivity to selenium. Journal of Plant Nutrition 31:1232-1242.

Holtzclaw KM, Neal RH, Sposito G, Traina SJ (1987). A sensitive colorimetric method for the quantitation of selenite in soil solutions and natural waters. Soil Science Society of America Journal 51:75-78.

$\mathrm{Hu}$ Y, Schmidhalter U (2005). Drought and salinity: A comparison of their effects on mineral nutrition of plants. Journal of Plant Nutrition and Soil Science 168:541-549.

Ibrahim HM (2014). Selenium pretreatment regulated the antioxidant defence system and reduces oxidative stress on drought-stressed wheat (Triticum aestivum L.) plants. Asian Journal of Plant Science 13(3):120-128.

Kabata-Pendias A, Pendias H (2001). Trace elements in soils and plants. CRC, Boca Raton, FL.

Karimi HR, Hasanpour Z (2014). Effects of Salinity and Water Stress on Growth and Macro Nutrients Concentration of Pomegranate (Punica granatum L.). Journal of Plant Nutrition 37(12):1937-1951.

Kopsell DA, Randle WM, Mills HA (2000). Nutrient accumulation in leaf tissue of rapid-cycling Brassica oleracea responds to increasing sodium selenate concentrations. Journal of Plant Nutrition 23(7):927-935.

Kostopoulou P, Barbayannis N, Noitsakis B (2010). Water relations of yellow sweetclover under the synergy of drought and selenium addition. Plant and Soil 330:65-71.

Kostopoulou P, Karatassiou M, Barbayiannis N (2012). Effect of limited water supply on Melilotus officinalis nutrient content. Options Méditerranéennes 102:84-86.

Kostopoulou P, Parissi ZM, Abraham EA, Karatassiou M, Kyriazopoulos AP Barbayiannis N (2015). Effect of selenium on mineral content and nutritive value of Melilotus officinalis L. Journal of Plant Nutrition 38:1849-1861.

Kuznetsov VV, Kholodova VP, Kuznetsov VV, Yagodin BA (2003). Selenium regulates the water status of plants exposed to drought. Doklady Biological Sciences 390:266-268.

Li HF, McGrath SP, Zhao FJ (2008). Selenium uptake, translocation and speciation in wheat supplied with selenate or selenite. New Phytologist 178:92-102.

Mackowiak CL, Amacher MC (2003). Plant uptake of selenium in phosphate shale deposits and mine waste rock dumps. Western Nutrient Management Conference, Salt Lake City,
UT pp 136-148.

Marschner H (1995). Mineral Nutrition of Higher Plants. Academic Press, London.

Mayland HF (1994). Selenium in plant and animal nutrition. In: Frankenberger WT, Benson S (Eds). Selenium in the Environment, Marcel Dekker Inc, New York pp 29-45.

McLaughlin SB, Wimmer R (1999). Transley Review No. 104 Calcium physiology terrestrial ecosystem processes. New Phytologist 142:373-417.

Mengel K, Kirkby EA (2001). Principles of Plant Nutrition, $5^{\text {th }}$ ed. Kluwer Academic Publishers, NL.

Mueggler WF, Stewart WL (1980). Grassland and shrubland habitat types of western Montana. Gen. Tech. Rep. INT-66. Ogden, UT, U.S.: Department of Agriculture, Forest Service, Intermountain Forest and Range Experiment Station.

Nawaz F, Ashraf MY, Ahmad R, Waraich EA, Shabbir RN (2014). Selenium (Se) regulates seedling growth in wheat under drought stress. Advances in Chemistry http://dx.doi.org/10.1155/2014/143567.

Nejat F, Dadniya M, Shirzadi MH, Lak S (2009). Effects of drought stress and selenium application on yield and yield components of two maize cultivars. Plant Ecophysiology 2:95102.

Palta JP (1990). Stress Interactions at the Cellular and Membrane Levels. Horticultural Science 25(11):1377-1381.

Patakas A, Nikolaou N, Zioziou E, Radoglou K, Noitsakis B (2002). The role of organic solute and ion accumulation in osmotic adjustment in drought-stressed grapevines. Plant Science 163:361-367.

Pazurkiewicz-Kocot K, Galas W, Kita A (2003). The effect of selenium on the accumulation of some metals in Zea mays $\mathrm{L}$. plants treated with indole-3-acetic acid. Cellular and Molecular Biology Letters 8:97-103.

Pinkerton A, Simpson JR (1986). Interactions of surface drying and subsurface nutrients affecting plant-growth on acidic soil profiles from an old pasture. Australian Journal of Experimental Agriculture 26:681-689.

Proietti P, Nasini L, del Buono D, D’Amato R, Tedeschini E, Businelli D (2013). Selenium protects olive (Olea europaea L.) from drought stress. Scientia Horticulturae 164:165-171.

Rogers PAM (1990). Selenium toxicity in farm animals: Treatment and prevention. Irish Veterinary Journal 43:151153.

Romero P, Navarro JM, Garcia F, Ordaz PB (2004). Effects of regulated deficit irrigation during the pre-harvest period on gas exchange, leaf development and crop yield of mature almond trees. Tree Physiology 24:303-312.

Saggoo MIS Dhillon KS, Dhillon SK, Kour J (2004). Evaluation of consumability potentials of leafy vegetables harvested from selenium rich soil. Environmental Information Archives 2:479-489.

Samarah N, Mullen R, Cianzio S (2004). Size distribution and mineral nutrients of soybean seeds in response to drought 
454 stress. Journal of Plant Nutrition 27:815-835.

Seppanen M, Turakainen M, Hartikainen H (2003). The effect of selenium on photooxidative stress tolerance in potato. Plant Science 165:311-319.

Simojoki A, Xue T, Lukkaru K, Pennänen A, Hartikainen H (2003). Allocation of added selenium in lettuce and its impact on roots. Agricultural and Food Science 12:155-164.

Soleimanzadeh H (2012). Response of sunflower (Helianthus annuus L.) to selenium application under water stress. World Applied Sciences Journal 17(9):1115-1119.

Tennant T, Wu L (2000). Effects of water stress on selenium accumulation in tall fescue (Festuca arundinacea Schreb) from a selenium-contaminated soil. Archives of Environmental Contamination and Toxicology 38:32-39.

Terry N, Zayed M, De Souza MP, Tarun AS (2000). Selenium in higher plants. Annual Review of Plant Physiology and Plant Molecular Biology 51:401-432.

USDA-NRCS (1996). Keys to soil taxonomy. USDA-NRCS, Washington, DC.

Utrillas MJ, Alegre L, Simon E (1995). Seasonal changes in production and nutrient content of Cynodon dactylon (L.) Pers. Subjected to water deficits. Plant and Soil 175:153-157.

Valadabadi SA, Shiranirad AH, Farahani HA (2010). Ecophysiological influences of zeolite and selenium on water deficit stress tolerance in different rapeseed cultivars. Journal of Ecology and Natural Environment 2(8):154-159.

Valliyodan B, Nguyen H (2006). Understanding regulatory networks and engineering for enhanced drought tolerance in plants. Current Opinion in Plant Biology 9(2):189-195.

Viets Jr FG (1972). Water deficits and nutrient availability. In: Kozlowski TT (Ed). Water Deficits and Plant Growth. Vol III Plant Responses and Control of Water balance. Academic Press, New York, USA pp 217-240.
Waraich EA, Saifullah RA, Ehsanullah MYA (2011). Role of mineral nutrition in alleviation of drought stress in plants. Australian Journal of Crop Science 5(6):764-777.

Wu L, Enberg A, Biggar JA (1994). Effects of elevated selenium concentration on selenium accumulation and nitrogen fixation symbiotic activity of Melilotus indica L. Ecotoxicology and Environmental Safety 27:50-63.

Wu L, Enberg A, Tanji K (1993). Natural establishment and selenium accumulation of herbaceous plant species in soils with elevated concentrations of selenium and salinity under irrigation and tillage practices. Ecotoxicology and Environmental Safety 25:127-140.

Wu L, Van Mantgem PJ, Guo X (1996). Effects of forage plant and field legume species on soil selenium redistribution, leaching, and bioextraction in soils contaminated by agricultural drain water sediment. Archives in Environmental Contamination and Toxicology 31:329-338.

Wu L, Huang ZZ (1992). Selenium assimilation and nutrient element uptake in white clover and tall fescue under the influence of sulphate concentration and selenium tolerance of the plants. Journal of Experimental Botany 43(4):549-555.

Xue T, Hartikainen H, Piironen V (2001). Antioxidative and growth-promoting effect of selenium on senescing lettuce. Plant and Soil 237: 55-61.

Zhu X, Gong H, Chen G, Wang S, Zhang C (2005). Different solute levels in two spring wheat cultivars induced byprogressive field water stress at different developmental stages. Journal of Arid Environments 62:1-14. 